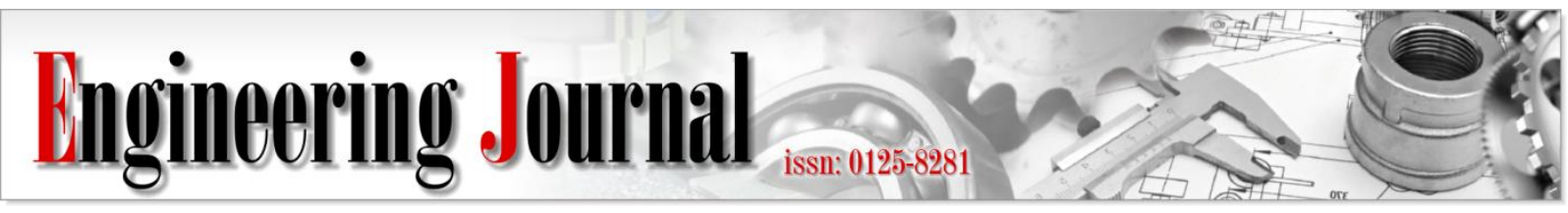

Article

\title{
Modelling the Impact of Nigeria Household Energy Policies on Energy Consumption and $\mathrm{CO}_{2}$ Emissions
}

\author{
Michael O. Dioha \\ Department of Energy and Environment, TERI School of Advanced Studies, 10 Institutional Area, Vasant \\ kunj, New Delhi-110070, India \\ E-mail:michael.dioha@terisas.ac.in,mdioha@ymail.com
}

\begin{abstract}
Energy security, environmental degradation, and climate change have become global topics of discussion. In response to these issues, the federal government of Nigeria has developed the National Renewable Energy and Energy Efficiency Policy (NREEEP). In this policy document, some programs were outlined for the Nigerian household sector. A major initiative in the household energy policies is to incorporate energy efficient appliances in all households by 2030. Here, we use the Long-range Energy Alternatives Planning Systems modelling framework to analyse the effect of these policies on final energy demand and $\mathrm{CO}_{2}$ emissions. The paper also goes ahead to look at the knock-on effects if the policies are sustained up to mid-century. Two scenarios are developed; the reference (REF) scenario and the energy policy (EPO) scenario. Results show that final energy demand of the Nigerian residential sector will increase from around 826 PJ in 2010 to 1580 PJ in 2030 and will further increase to 3011 PJ by 2050 in the REF scenario. In the same scenario, $\mathrm{CO}_{2}$ emissions increased from $6.1 \mathrm{MtCO}_{2} \mathrm{e}$ in 2010 to around 15.4 and 37.2 $\mathrm{MtCO}_{2} \mathrm{e}$ in 2030 and 2050 respectively. Our analysis suggests that if the household energy policies are fully implemented in the EPO scenario, about $61 \%$ and $58 \%$ reduction in energy demand is achievable by 2030 and 2050 respectively when compared to the REF scenario. The study further indicates that the direct total $\mathrm{CO}_{2}$ emissions in the EPO scenario will increase by around $170 \%$ and $124 \%$ by 2030 and 2050 respectively, when compared with the REF case. Our findings indicate that the current household energy policies are not effective from the perspective of climate change mitigation. Hence, complementary policies are recommended.
\end{abstract}

Keywords: Energy policy, energy demand, $\mathrm{CO}_{2}$ emissions, LEAP, Nigeria, household.

ENGINEERING JOURNAL Volume 22 Issue 6

Received 3 June 2018

Accepted 18 August 2018

Published 4 December 2018

Online at http://www.engj.org/

DOI:10.4186/ej.2018.22.6.1 


\section{Introduction}

The $5^{\text {th }}$ assessment report of the Intergovernmental Panel on Climate change (IPCC) established the impact of anthropogenic activities on the climate. The report indicated that anthropogenic greenhouse gas (GHG) emissions have increased since the pre-industrial era which has been driven mainly by population and economic growth. This has led to higher concentrations of carbon dioxide, nitrous oxide, and methane in the atmosphere [1]. The impact of climate change is felt by everyone and is seen in the melting of the polar ice caps and the rising of the sea levels. Most GHG emissions arise from energy-related activities such as combustion of fossil fuels for electricity generation, transportation, and other economic activities. This has become the reason why energy production and consumption pattern has been given special attention in tackling climate change. To reduce GHG emissions and thus combat climate change, the use of renewable energy technologies is required [2]-[4].

Climate change has had severe impacts in Nigeria in the past decade. For examples; the Post Disaster Need Assessment (PDNA) report following the 2012 flood in Nigeria showed that the total worth of the damage amounted to USD 17 billion which was about $1.4 \%$ of the real GDP in that year [5]. The drying up of Lake Chad from around $45000 \mathrm{~km}^{2}$ in 1960 to below $3000 \mathrm{~km}^{2}$ in 2007 is mainly because of the increasing adverse effects of climate change in that region. Also, hydro-electric power generation has been highly impacted on negatively from low water inflow into the dams and water transportation is also getting difficult [6]. Considering these severe problems, climate change poses a daunting threat to the achievement of Nigeria socio-economic development goals.

Nigeria is a signatory to the United Nations Framework Convention on Climate Change (UNFCCC), Kyoto protocol, and Paris Accord. It has also been actively participating in the global action to mitigate climate change. The federal government of Nigeria has developed the National Renewable Energy and Energy Efficiency Policy (NREEEP) with the objective of providing energy security as well as mitigating climate change. The policy document outlined robust programs that include large-scale deployment of renewable energy technologies and the use of energy efficient technologies in the agriculture, commercial, transport, industry and residential/household sectors of Nigeria [7]. The policies for the household sector states that the Nation shall encourage the use of energy-efficient and environmentally safe technologies in the household and provision of access to clean and modern fuels by 2030. The document also laid down the short, medium and long terms strategies for achieving these policies [7].

The household sector is therefore, not left out in the efforts towards combating climate change as this sector also contributes to national GHG inventory. Most of the household energy-related activities like lighting and cooking produce GHGs [8]. Furthermore, the use of fossil fuel-based generators as backup for the unstable power supply in the residential sector accounts for high GHGs emissions. It has been estimated that a $5 \mathrm{~kW}$ diesel generator can produce twice the emissions of a coal power plant which is usually regarded as the main cause of environmental pollution and produces about $1000 \mathrm{gCO}_{2} / \mathrm{kWh}$ [9], [10].

Carbon dioxide $\left(\mathrm{CO}_{2}\right)$ has been identified as the most prominent GHG which is produced by anthropogenic activities and accounts for about $60 \%$ of the increase in climate forcing since the pre-industrial era. It is estimated that about 1440 billion tonnes of $\mathrm{CO}_{2}$ have been released into the atmosphere between $1751-2013$ [11]. $\mathrm{CO}_{2}$ is not harmful to plants but dangerous to the climate with respect to human survival. The increase of $\mathrm{CO}_{2}$ in the atmosphere warms the lower atmosphere and cools the upper atmosphere and this result to increase in the global surface temperature. $\mathrm{CO}_{2}$ stays for a very long time in the atmosphere compared to other GHGs. Methane $\left(\mathrm{CH}_{4}\right)$ emissions take about 10 years to leave the atmosphere and possibly converts into $\mathrm{CO}_{2}$ while Nitrous oxide $\left(\mathrm{N}_{2} \mathrm{O}\right)$ takes about 100 years to leave the atmosphere. However, for $\mathrm{CO}_{2}$, most of the emissions will leave the atmosphere before 100 years but a fraction of $20 \%$ will remain and still exist in the atmosphere for over 700 years from the time of emission. This implies that our unborn generations will suffer the consequences of our actions today if serious efforts are not taken towards reducing $\mathrm{CO}_{2}$ emissions [12].

Energy system models are used to describe and explore the futures of the energy system of a sector or region. They are used to inform policy makers about the effectiveness and implications of various energy and climate policies. Generally, two types of energy system models are used to analyse energy demand and GHG emissions, namely: bottom-up engineering models and top-down macroeconomic models [13].

The bottom-up models use an engineering approach to allow a detailed representation of technologies using different data but differ much in addressing energy consumption. They are further categorised as (i) optimisation models (ii) simulation/accounting framework models and (iii) multi-agent models [14], [15]. The optimisation models are used to find the optimal/least cost choice of technologies to achieve a specific 
objective given certain constraints [16]. Examples are MARKAL/TIMES and MESSAGE. The simulation models which are often described as the accounting framework type of models are used to simulate energy demand based on various energy demand drivers like population and GDP and does not attempt to minimise cost. Examples are LEAP and MAED [15]. The multi-agent models describe market imperfections like strategic behavior and other non-economic parameters.

On the other hand, the top-down models describe the energy system as a whole in aggregate relationship or on a national level. They normally consider energy demand through economic variables like GNP, prices elasticities, exports and imports [17]. They are further categorised as follows: (i) input-output models (ii) econometric models (iii) general equilibrium models and (iv) system dynamics model [15]. The input-output models are used to provide a framework for describing the flow of a country's goods and services within the various sectors of the economy. The econometric models use statistical relationships between economic variables to make projections. The general equilibrium models describe the equilibrium of market optimum prices and quantities [15]. The system dynamics models are used to describe the interaction in social systems as a result of interdependencies while taking account of the dynamic changes over a period of time [18].

Over the years, there have been several studies on households using some of these models. Kannan and Strachan [19] modelled the UK household energy sector with the UK-MARKAL and UK residential housing stock models. The study was done in relation to the $60 \%$ reduction of $\mathrm{CO}_{2}$ emissions by 2050 as proposed by the UK government. Utsav and Amrit [20] combined the MAED and MARKAL models to study the energy usage pattern of the household sector of Kathmandu valley, Nepal. The base year demand was projected with the MAED model while the scenarios were developed with the MARKAL model. Ejigu [21] conducted a study on the energy consumption pattern of households in Bahir dar city, Ethiopia using the LEAP model. The study consisted of about 350 households which were selected by random sampling. The study was based on two scenarios; the business as usual and mitigation scenarios. In Nigeria, Ibitoye [22] used the LEAP model to study Nigeria energy requirements in view of achieving the Millennium Development Goals (MDG). The author established two scenarios; the Reference scenario and the MDG scenario and compared energy estimates for the period 2005 - 2020. The result of the study showed that household electricity energy demand will rise by $41 \%$ and the use of commercial fuels will double over the period of study. Though several other studies on Nigeria households are available in literature [23]-[31]; there have been no detailed academic analysis of the current households' renewable energy and energy efficiency policies.

Here we examine the impact of Nigeria household energy policies on energy consumption and $\mathrm{CO}_{2}$ emissions. We use the Long-range Energy Alternatives Planning System (LEAP) modelling framework to project Nigeria's household energy demand and corresponding $\mathrm{CO}_{2}$ emissions for the period $2010-2050$. Scenarios are developed to analyse the energy savings as well as the $\mathrm{CO}_{2}$ emissions reduction potentials of each household energy service sectors.

The remainder of this paper is structured as follows. Section 2 discusses the specific features of the Nigerian household sector. Section 3 explains the research methodology and assumptions used in the study which encompasses the LEAP model structure, input data and scenarios development. Section 4 presents the results and analysis while the conclusions of the study are stated in section 5.

\section{Nigeria Household Sector Characteristics}

In this section, we review the current energy scenario of Nigeria in order to understand the basis and approach for our energy demand projections. Total household energy consumption in Nigeria has gradually been increasing in the last decade. Between 2006 and 2015, Nigeria's household energy sector demand increased by around $30 \%$ [32]. This energy is usually consumed in the form of kerosene, liquefied petroleum gas (LPG), electricity, and biomass [7]. In 2015, the Nigeria household sector energy demand stood at 97661 ktoe which was about $81 \%$ of total final energy consumption in the country [32]. The main energy service requirements of Nigeria households are cooking, lighting, refrigeration, air conditioning, water heating and other electrical appliances such as fans and audio-visuals.

Lighting energy requirement in Nigeria households is mainly satisfied by electricity and kerosene. The electrified households which are concentrated in the urban areas use electricity and the non-electrified households which are mostly found in the rural areas depend on kerosene for lighting. Other sources of lighting like firewood, candles and dry cell battery torches are also used most especially in the rural areas. However, the urban dwellers sometimes resort to kerosene lantern and dry cell battery torch during blackouts which is very common in the country [33]. The technologies employed for electric lighting are the inefficient incandescent bulbs and the efficient fluorescent lamps (CFLs) and light-emitting diode (LED) bulbs. 
Air conditioning and refrigeration services are mainly localised in the urban areas. The energy requirement is completely satisfied by electricity. Most of the air conditioners and refrigerators in use are the inefficient types and they are very old. The commonly used air conditioning technology is the window unit, though the split unit type is gradually penetrating into the household sector. For refrigeration, the commonest technology in use is the fridge (combined with freezer). However, with the increasing urbanisation and increase in demand for comfort, the use of air conditioners and refrigerators will increase significantly in the future.

Cooking is the most energy intensive activity in Nigeria households. Cooking activities consume about $80 \%$ of total household energy consumption and biomass (firewood, charcoal, animal dung etc.) makes up about $90 \%$ of cooking fuel. The continual reliance on biomass has led to the clearing of many forests in the country and this contributes to climate change. Also, the pollution resulting from burning of biomass for cooking leads to respiratory diseases and has been responsible for about 79000 deaths annually in Nigeria [34]. Other cooking fuels in Nigeria household sector include kerosene and LPG. The use of LPG is quite marginal and can mostly be found in urban dwellings [35], [36]. This can be attributed to the price differential between the different cooking fuels, awareness, cultural preferences and the availability of the fuel. For example, most of the rural dwellers find it very easy to collect firewood for cooking since it is readily available at no cost. However, this won't be the case with kerosene and LPG which are expensive to purchase and sometimes not even available at vendors [35]. The technologies employed in cooking are usually the inefficient traditional three-stone stove system for burning fuelwood, kerosene, and LPG stoves.

Water heating is another energy service that consumes a significant amount of energy in the Nigeria household sector. Hot water is used for bathing and making of tea and other beverages which are usually served hot. However, the demand for hot water for bathing varies with the season. Nigeria has a tropical equatorial climate which is hot for most period of the year. Hence only a few people; most especially those in the urban areas use hot water for bathing. The technology commonly used for water heating in Nigeria households is the electric kettle which is concentrated in the electrified urban areas. Water heaters (geysers) are also used for water heating but can only be found in few homes in the urban areas as most homes were built without them. Many rural dwellers and non-electrified urban dwellers satisfy their hot water needs with the same technologies for cooking [23].

Other residential appliances such as ceiling fan, radio, and television consume significant amount of energy and account for about $60 \%$ of electricity use in households. These electrical appliances are usually owned by the electrified households. Ownership also depends on income as this can be observed in the urban-rural ownership dichotomy in the country. The current electrical appliances in use are mainly the inefficient types [37].

\section{Methodology and Assumptions}

In this paper, the LEAP modelling tool is applied to project Nigeria household energy demand and the associated $\mathrm{CO}_{2}$ emissions from 2010 - 2050. Energy modelling and scenario analysis are the commonest methods for energy policy analysis. Energy models are used to explore the future and the implications of energy policies in a quantitative approach. The results of the models are used to inform policy makers of the implications and effectiveness of various policies.

\subsection{The LEAP Model Structure}

LEAP is a scenario-based energy-economy-environment modelling tool developed by the Stockholm Environment Institute, Boston with financial support from the World Bank and United Nations Environment Program (UNEP). The LEAP model simulates energy scenarios with several modules and it's user-friendly and transparent. It uses an accounting framework to systematically analyse national energy systems by tracking energy consumption up to resource extraction. Working on the LEAP model consist of four modules; the assumptions, demand, transformation, and energy production modules. The data in LEAP are arranged in a hierarchical or tree format based on the sector level, sub-sector level, end uses and technologies. With respect to the demand side, LEAP endogenously calculates the energy demand as the product of the activity level and energy intensities for all end uses [38]. LEAP can analyse energy demand in four ways: final energy demand, useful energy demand, stock and transport analysis. The particular approach to use depends on the modeller, the research problem, and the available data. Energy demand in LEAP can be obtained from Eq. (1) - (4). 


$$
\text { Final Energy Analysis, } E=\sum_{i=1}^{n} Q_{I} \times I_{i}
$$

where $E=$ energy demand; $Q_{I}=$ activity level and $I_{I}=$ energy intensity

$$
\text { Useful Energy Analysis, } E=Q \times\left(\frac{u}{n}\right)
$$

where $u=$ useful energy intensity and $n=$ efficiency

$$
\text { Stock Analysis, } E=S \times D
$$

where $S=$ Stock and $D=$ device intensity

$$
\text { Transport Analysis, } E=S \times \frac{M}{F E}
$$

where $M=$ Vehicles miles and $F E=$ Fuel economy

GHG emissions are computed in LEAP as per equation 5.

$$
G=\sum E \times E f
$$

where $G$ represents the total GHG emission, $E$ energy demand by a given fuel and $E f$ the emission factor of the fuel.

LEAP also consist of a Technology and Environmental Database (TED) which provides information regarding the cost and environmental impacts of a portfolio of technologies available worldwide. This is possible because the LEAP model is equipped with the IPCC Tier 1 GHG emission factors ${ }^{1}$ (Global Warming Potentials from the IPCC assessment reports) and also air pollutants emission factors. The TED also include qualitative data in addition to the quantitative data that provides information on the appropriateness and major environmental concerns of a group of technologies. However, the TED does not encompass electricity emission factor for household demand because the emission factors of TED is for emissions at the point of release and as such, it doesn't include emissions from the upstream that occur during electricity generation [38]. For a detailed documentation of the LEAP model, see user guide [38].

For quantifying Nigeria household energy demand, the Nigeria household sector is disaggregated into urban and rural households. This is to show the common characteristics of urban-rural divide which is very common in developing countries like Nigeria. The energy consumption pattern of urban and rural dwellers varies considerably in Nigeria. Most urban dwellers are engaged in the industrial and services sectors and usually consume much of electrical energy in meeting domestic energy services such as refrigeration and air conditioning while most of the rural dwellers are engaged in agricultural activities and usually possess few electrical energy consuming devices [35]. The urban and rural lighting service demands are further disaggregated into electricity and kerosene lighting. This is to show further differences in the energy consumption pattern of electrified and non-electrified households. Figure 1 shows the disaggregation of Nigeria household sector.

\footnotetext{
${ }^{1}$ https://www.ipcc-nggip.iges.or.jp/EFDB/main.php
} 


\section{NIGERIA HOUSEHOLD}
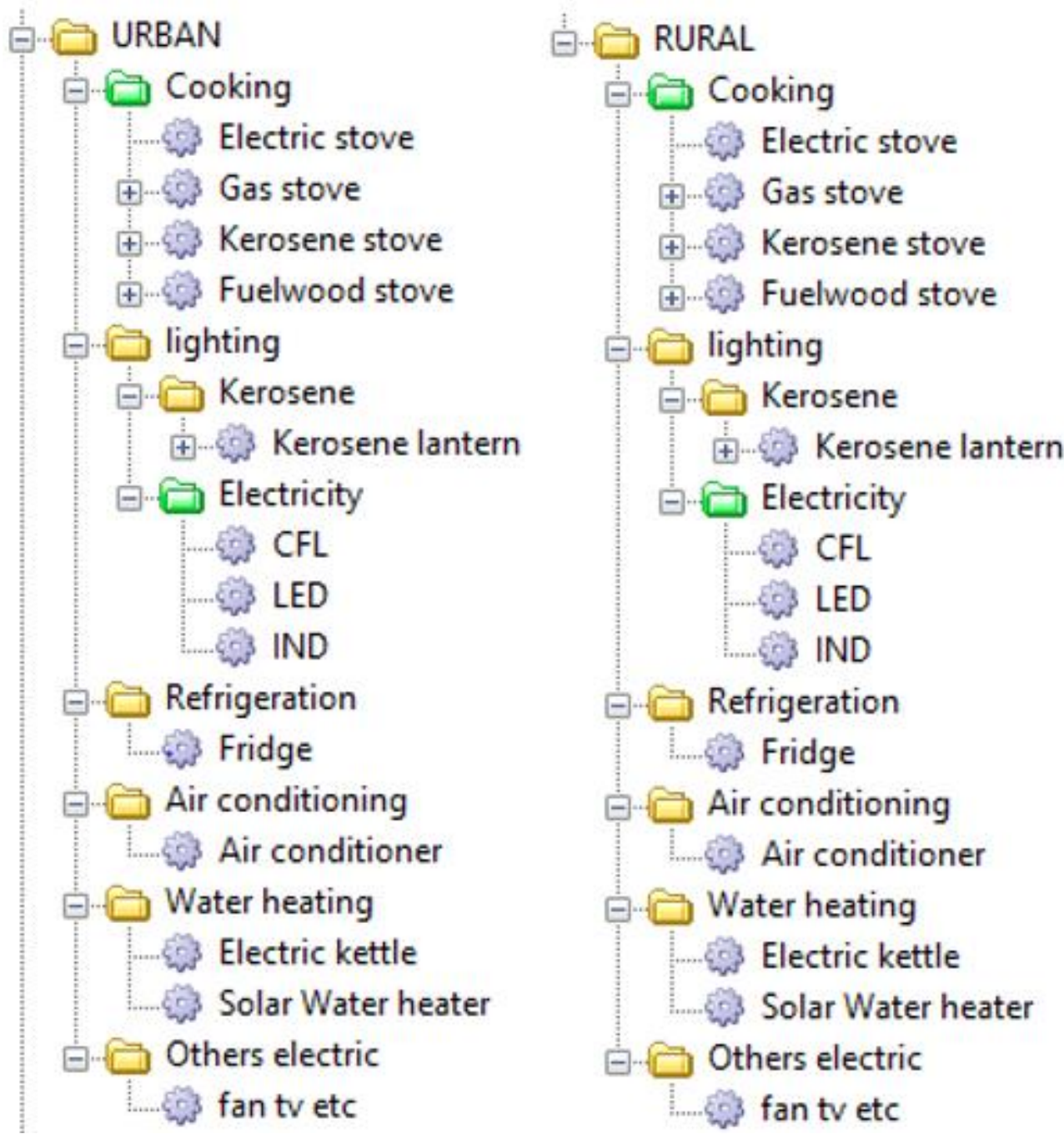

Fig. 1. Tree structure of Nigeria household LEAP model.

\subsection{Input Data and Energy Demand Drivers}

\subsubsection{Input data}

The current and future estimates of the total population and urbanisation level of Nigeria was taken from the United Nations 2015 medium variant revision of world population prospects [39]. The annual households' population growth rate was estimated from the Nigeria 1991 and 2006 population censuses [40], [41]. The household characteristics were taken from the following sources: Living Standard Measurement Surveys published by the Nigeria Bureau of Statistics [33], [42], Renaissance capital survey of Nigeria middle class [43] and the report of the end-use metering campaign of residential houses in Nigeria which has been published by the Energy Commission of Nigeria (ECN) in collaboration with the Federal Ministry of Environment (FMENV), United Nations Development Program (UNDP) and the Global Environment Facility (GEF) [37]. The annual growth rate of household appliances ownership has been estimated from the 2003 Nigeria demographic and health survey conducted by the Nigeria Population Commission (NPC) [44] and the Nigeria Energy Calculator (NECAL) 2050 report [45]. 


\subsubsection{Drivers of energy demand}

Number of households, population growth rate and level of urbanisation are very pertinent for household energy demand analysis. Here, these parameters have been used as the driving factors of Nigeria household energy demand. As population and urbanisation increases, it is expected that the demand for energy services will also increase and vice versa. In reality, other factors like income, cultural preferences, and energy prices may affect energy demand but, we didn't consider them in this paper.

The population of Nigeria in 2010 was around 160 million and it has been estimated to grow at a rate of $2.6 \%$ and gradually decline to a rate of $2.3 \%$ by 2030 and $1.8 \%$ by 2050 corresponding to a population of approximately 400 million persons by 2050 . Urbanisation in 2010 was $43.6 \%$. It has been projected to increase up to $60.6 \%$ by 2030 and $74 \%$ by 2050 . The total number of households in 1991 and 2006 was 16,448,944 and 28197085 respectively and we have projected it to continue growing at an annual rate of $3.6 \%$ to around 122 million by 2050 . The future projections of population and number of households are presented in Figs. 2 and 3 respectively.

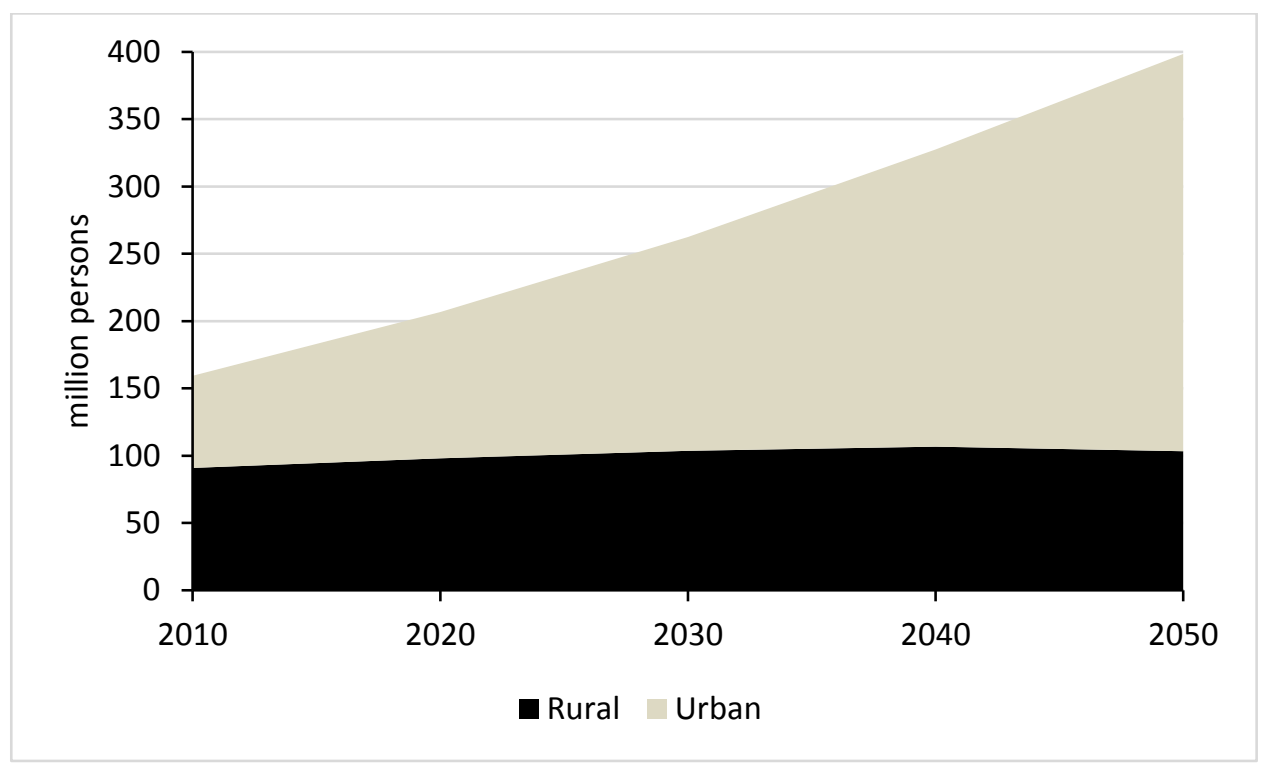

Fig. 2. Nigeria Population projection.

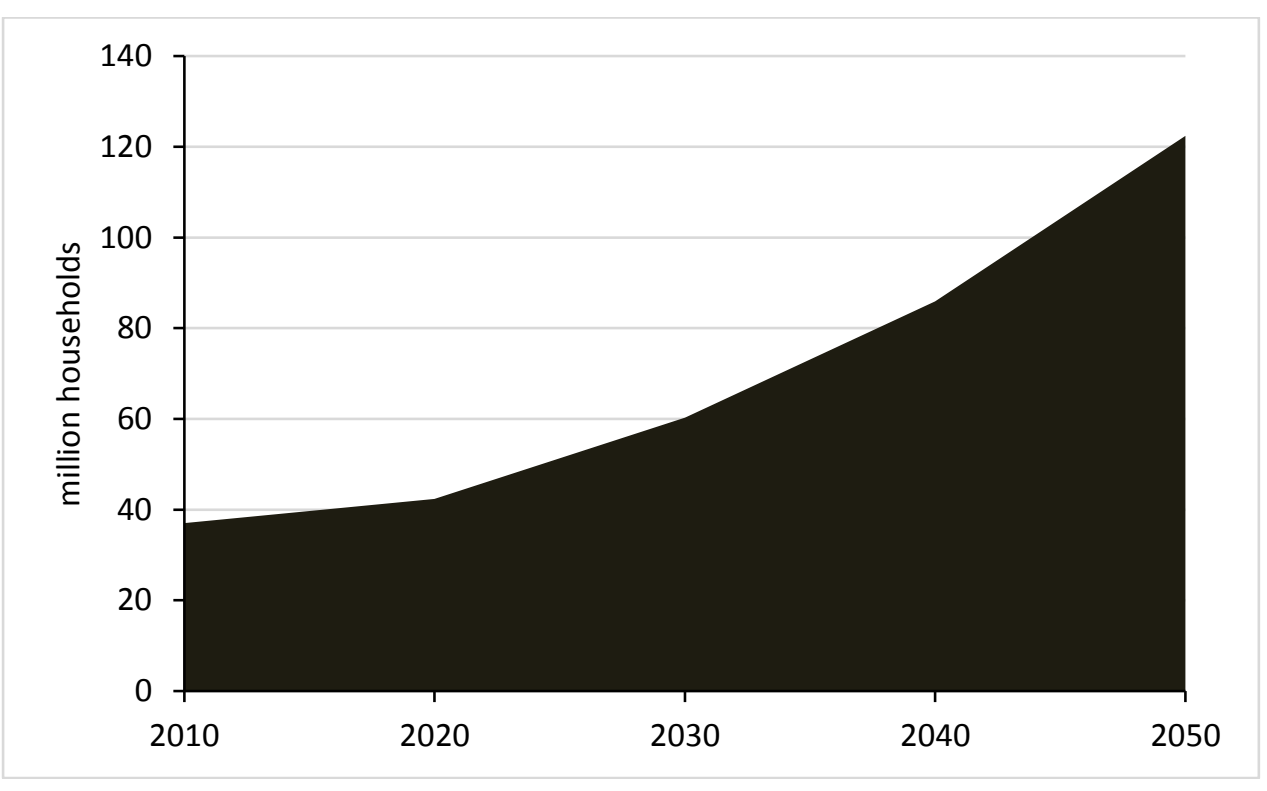

Fig. 3. Nigeria number of households' projection. 


\subsection{Scenarios Development}

Scenario analysis is used in this study to explore the energy demand and GHG mitigation potentials of Nigeria household energy policies. In doing the same, two scenarios are developed, namely: Reference (REF) scenario and Energy Policy (EPO) scenario.

\subsubsection{Reference (REF) scenario}

Energy services information used in creating the REF scenario are described as follows:

Cooking: Useful energy analysis is done for the cooking sector. This is achieved in LEAP by providing the useful energy intensity of cooking and the efficiencies of the cooking technologies. In 2010, the activity levels of cooking fuels in the urban households were $51.7 \%$ kerosene, $2.1 \%$ gas, $0.8 \%$ electricity, and $45.5 \%$ fuelwood. In the same year, $7.9 \%$ of the rural dwellers depend on kerosene; $0.4 \%$ gas; $0.2 \%$ electricity, and $91.5 \%$ depend on fuelwood for cooking. The useful energy intensity for cooking in Nigeria is given as 800 $\mathrm{MJ} /$ capita/year as in [35]. However, this value is being multiplied by 5.5 and 6.0 which are the average sizes for urban and rural households respectively and thus, the useful energy intensity used in this study is estimated at $4400 \mathrm{MJ} /$ household/year and $4800 \mathrm{MJ} /$ household/year for the urban and rural households respectively. The efficiencies of the cooking technologies are given as $95 \%, 60 \%, 55 \%$ and $18 \%$ for electric stove, gas stove, kerosene stove and traditional three-stone stove respectively [30].

Lighting: lighting demand is satisfied by electricity in the electrified households and kerosene in the nonelectrified households. However, other sources of lighting like wood, grass, candle and dry cell batteries are also used for lighting most especially in the rural areas. In this study, we consider these other sources of lighting as part of kerosene lighting. In 2010, electricity access rate in Nigeria was at an average of 55.9\%. The urban and rural households had access rates of $87.1 \%$ and $35.5 \%$ respectively. With respect to lighting technologies, $41 \%$ of urban households make use of incandescent bulbs, $58 \%$ use CFLs, and only $1 \%$ use LED bulbs while we assume that $80 \%$ of the rural dwellers use incandescent bulbs and the remaining $20 \%$ use CFLs. The average annual household lighting energy intensity is $454 \mathrm{kWh} /$ household of electricity [37]. Using incandescent bulb as a base (100\% efficiency), we estimated the efficiencies of CFL and LED as five and ten times higher respectively relative to the incandescent bulb. Also, for the non-electrified households, we assume that kerosene lanterns are the only means of lighting. Since most of the lighting is done in the night between $3-7$ hours daily and based on local experts' opinions, we assume that only $10 \%$ of the total annual household kerosene consumption is used for lighting. The kerosene consumption per household in 2010 has been estimated at 81 liters [32]. Using this value, the energy intensity of kerosene for lighting has been estimated at $281 \mathrm{~kJ} /$ household/year.

Refrigeration: The energy demand for refrigeration service is satisfied by electricity. In $2010,42 \%$ of the urban dwellers and $8.3 \%$ of rural dwellers had refrigerators. The annual growth rate of refrigerator ownership in the urban and rural households is estimated at $2.2 \%$ and $0.7 \%$ respectively. The energy intensity of refrigerator (fridge) is given as $496 \mathrm{kWh} /$ household/year [37].

Air conditioning: Air conditioner requires energy in the form of electricity. In 2010, 4.4\% of the urban dwellers and $0.9 \%$ of rural dwellers had air conditioners. It has been estimated that by $2050,75 \%$ and $15 \%$ of urban and rural households respectively will own air conditioner. The energy intensity of air conditioners is given as $828 \mathrm{kWh} /$ household/year [37].

Water Heating: Water heating requirement is mainly satisfied by electricity. The commonest technologies in use for water heating are the electric kettle and electric heater (geysers). Electric kettles/heaters in Nigeria households are rated $2 \mathrm{~kW}$ on average and are used daily for an average time of 30 minutes [46]. For annual energy intensity, it has been estimated at $365 \mathrm{kWh} /$ household/year. An average of $62 \%$ of urban households own electric heater and kettle [23], while we estimated an average of $18 \%$ ownership in the rural areas. 
Other electrical appliances (fan, TV, and iron): These appliances mainly require energy in the form of electricity for operation. In 2010, an average of $67 \%$ of the urban dwellers and $25 \%$ of rural dwellers own these appliances. The annual growth rate of these other electrical appliances ownership in the urban and rural households is estimated at $1.2 \%$ and $1.5 \%$ respectively. The energy intensity of audio-visual (TV, DVD player, and radio) is given as $122 \mathrm{kWh} /$ household/year [37]. However, with the inclusion of other appliances, an energy intensity of $250 \mathrm{kWh} /$ household/year has been assumed in this study.

The REF scenario is developed under the assumption that the number of households and other energy demand driving parameters will continue to grow in the current trend as highlighted in section 3.2.2. It is also assumed that technologies and energy efficiency pattern will remain in the status quo without any policy intervention.

\subsubsection{Energy policy (EPO) scenario}

The NREEEP declared the nation's intent to increase energy security, improve energy access especially in the rural areas, create employment and the protection of the environment. The demand side of the energy sector has been identified for potentials of energy saving through energy efficiency, renewable energy technologies, and energy conservation measures [7].

With respect to the household sector, the NREEEP states that the nation shall encourage the use of renewable energy technologies and energy-efficient appliances for cooking, heating, air conditioning, lighting etc. The main program of the household energy policies is to introduce energy efficiency standards and state of the art technologies for households. The strategies identified in achieving these policies are grouped into short, medium, and long terms and can be summarised as follows:

\section{Short term (2015)}

- Encouraging the use of energy efficient stoves and renewable energy technologies such as solar water heaters.

- Introduction of labelling for household appliances.

- Promoting the uses of LED and CFL bulbs and phasing-out of incandescent bulbs Medium term (2020)

- Consolidation of short term strategies.

- Addition of energy efficiency standards to the National building code.

- Introduction of smart meters in all households by 2025 .

Long term (2030)

- Consolidation of medium term strategies.

- $100 \%$ access to clean energy and use of LPG for cooking in all households by 2030 .

- $40 \%$ reduction of energy intensities by 2030 .

Given this background, this scenario is developed on the premise that everything stated in the NREEEP for households will be achieved by 2030 while the energy demand drivers will continue in the same trend as in the REF scenario. Energy services information modelled in this scenario are described as follows:

Cooking: Energy efficiency in cooking can be achieved by replacing the poor domestic cookstoves with improved ones just as in the NREEEP. We therefore, assume that the energy intensity for cooking will reduce by $10 \%$ in 2020 and $40 \%$ by 2030 in both urban and rural households. We also assume that by 2030 , all households will switch to LPG as the only source of cooking fuel. The interpolation function of LEAP is used in this regard for both urban and rural households.

Lighting: It is expected that all households will be electrified by 2030 and as such, electricity will become the only sources of lighting. Energy efficiency in household lighting system can be achieved by replacing energy inefficient lamps with efficient ones. We assume that the Nigerian government and other stakeholders in the Nigeria energy sector begin to encourage the use of energy-saving lamps and demand side management (DSM) techniques and by 2015 , both urban and rural households will gradually start replacing incandescent bulbs with energy efficient bulbs. Thus, we assume that the use of incandescent bulbs will end by 2025 and 2030 in the urban and rural households respectively. Also, we assume that the government will sustain efforts in 
encouraging best energy efficiency practices and by 2025 the share of CFLs and LEDs will be 75\%, and 25\% respectively in urban households and the same in rural households by 2030. In this scenario, we further assume that electrification rate in the urban households of the country will hit $100 \%$ by 2025 . For the rural households, we assume that electricity access will reach $65 \%$ by 2020 and with much efforts by the government through rural electrification projects, it will become $100 \%$ by 2030 . Hence, the use of kerosene lantern for lighting will be totally stopped by 2030 .

Air conditioning, refrigeration, and other electrical appliances: The electricity use of air conditioners and refrigerators are rapidly increasing as the technologies are getting old and thus becoming more inefficient. Here we assume that government will keep raising awareness on the benefits of energy efficiency and introduction of labelling for residential energy appliances. We also assume that government will set up and begin to implement Minimum Energy Performance Standards (MEPS) and thus, both producers and consumers begin to shift towards energy efficient appliances. We therefore, assume that with the introduction of more energy-efficient air conditioners, refrigerators and other electrical appliances, energy intensities of these appliances will reduce by $10 \%$ in 2020 and $40 \%$ in 2030 .

Water heating: Here we assume that the government begins to provide incentives such as a subsidy for renewable energy technologies. Therefore, households will gradually start installing solar water heaters to conserve energy and in turn reduce energy demand from central utility and by 2030, the use of electricity for heating in all households will reduce by $10 \%$. The interpolation function of LEAP is being used in this regard for both rural and urban households.

\section{Results and Analysis}

\subsection{Energy Demand}

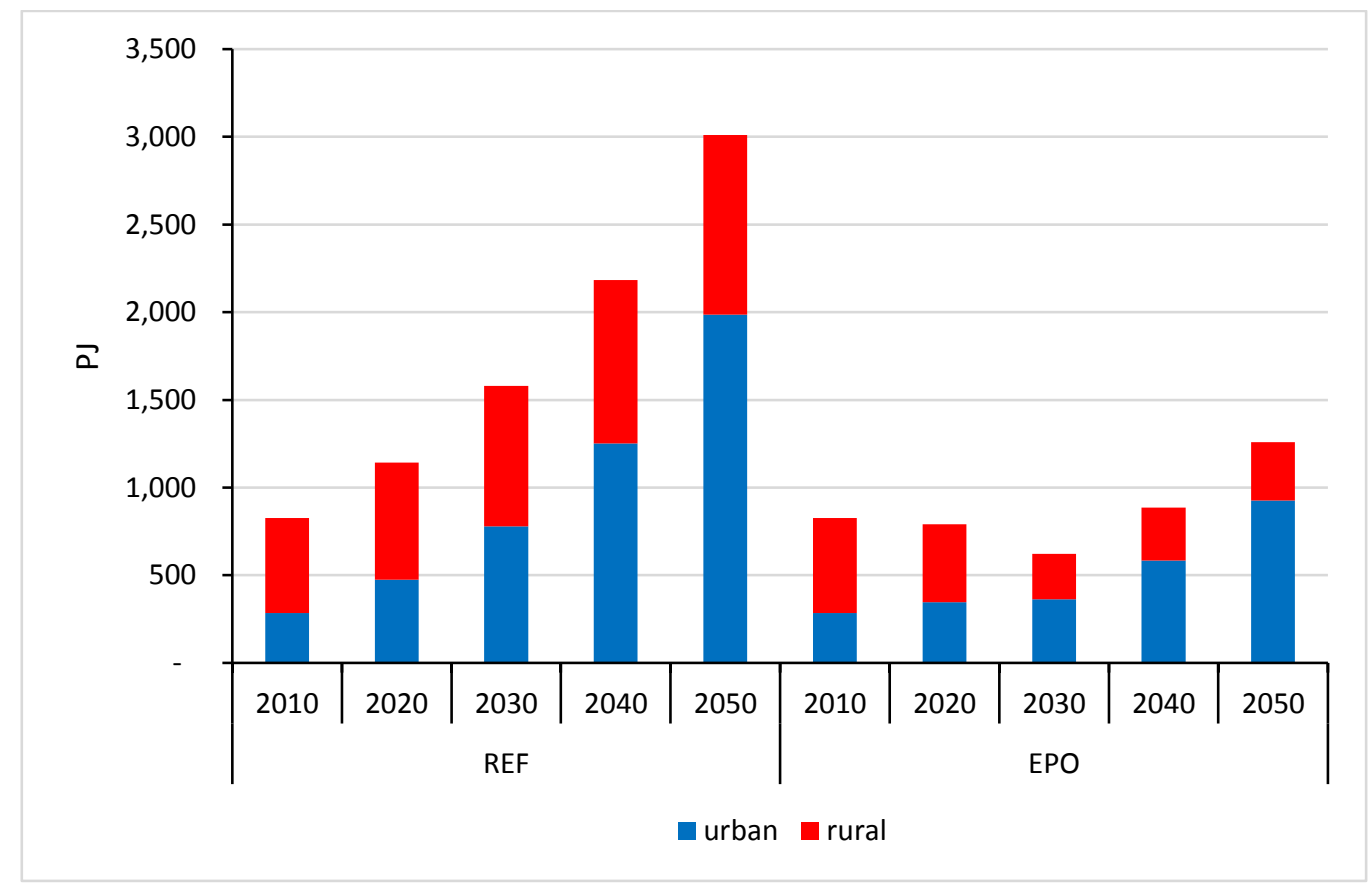

Fig. 4. Total final energy demand projection in the two scenarios.

From Fig. 4, energy demand is expected to increase steadily under the two scenarios up to 2050. Results indicate that total final energy demand in the REF scenario will increase at an annual rate of $3.47 \%$ from 826 PJ (Petajoule) in the base year to 1580 PJ in 2030 and will further increase by 2050 to 3011 PJ, which is about two and four times increases respectively compared to the base year. Analysis also showed that for urban households, energy demand will increase from 284 PJ in 2010 to 778 PJ in 2030 which is roughly 200\% 
increase while in the rural households' energy demand will increase from 542 PJ to 802 PJ in 2030 which represents about $48 \%$ increase. The result suggests that $49 \%$ and $66 \%$ of the total final energy demand by 2030 and 2050 respectively will come from the urban households. This is can be attributed to the expected increase in urbanisation by 2030 and 2050 as more people move from the rural areas to the urban areas and this will, in turn, increase the energy demand of the urban households. Detailed energy demand projections under the REF scenario are shown in Table 1.

Figure 4 also shows the total final energy demand in the EPO scenario. The results show that total final energy demand will decrease at an annual rate of $1.41 \%$, from 826 PJ in the base year to 622 PJ by 2030 which corresponds to a decrease of $24.7 \%$. However, it will further increase to $1258 \mathrm{PJ}(52.3 \%)$ in 2050 compared to the base year. The increase in energy demand after 2030 is due to the fact that though the current policies are in place, other energy demand drivers like the number of households will continue to increase even beyond 2030. Consequently, the demand for energy will continue to rise. It is therefore important to promote other policies that can reduce energy demand even after 2030. This result will be important for energy policy decisions beyond 2030 .

Table 1. Breakdown of energy demand projection under REF scenario (PJ).

\begin{tabular}{lrrrrr}
\hline Branch & $\mathbf{2 0 1 0}$ & $\mathbf{2 0 2 0}$ & $\mathbf{2 0 3 0}$ & $\mathbf{2 0 4 0}$ & $\mathbf{2 0 5 0}$ \\
\hline Urban total & 284.1 & 475.4 & 777.8 & $1,251.4$ & $1,986.8$ \\
Cooking & 248.8 & 416.4 & 681.3 & $1,096.2$ & $1,740.3$ \\
lighting & 12.1 & 20.3 & 33.1 & 53.3 & 84.6 \\
Refrigeration & 2.6 & 4.4 & 7.2 & 11.6 & 18.4 \\
Air conditioning & 0.1 & 0.2 & 0.3 & 0.4 & 0.7 \\
Water heating & 14.8 & 24.8 & 40.6 & 65.4 & 103.8 \\
Others electric & 5.6 & 9.3 & 15.3 & 24.6 & 39.1 \\
Rural total & 542.0 & 667.6 & 802.2 & 930.9 & $1,024.3$ \\
Cooking & 524.4 & 646.0 & 776.2 & 900.7 & 991.1 \\
lighting & 10.2 & 12.5 & 15.1 & 17.5 & 19.2 \\
Refrigeration & 0.3 & 0.3 & 0.4 & 0.4 & 0.5 \\
Air conditioning & 0.0 & 0.0 & 0.0 & 0.0 & 0.0 \\
Water heating & 5.5 & 6.8 & 8.1 & 9.4 & 10.4 \\
Others electric & 1.7 & 2.0 & 2.5 & 2.9 & 3.1 \\
Grand total & 826.1 & $1,143.0$ & $1,580.1$ & $2,182.3$ & $3,011.1$ \\
\hline
\end{tabular}

With respect to energy demand reduction, Fig. 5 shows that total final energy consumption will drop considerably in the EPO scenario. The result suggests a reduction of $958 \mathrm{PJ}$ in total final energy demand by 2030 which represents approximately 61\% reduction when compared to the REF scenario. Analysis also indicate that about $56.6 \%$ of energy savings will come from rural households in 2030 , as they all gradually move away from the use of traditional biomass to modern fuels for their energy services. If the energy efficiency policies are further maintained up to 2050 , about $58 \%$ or 1753 PJ could be saved compared to the REF scenario. We also observed that energy savings in 2050 will be more in the urban areas accounting for around $60.5 \%$ of the total energy savings which is because of urbanisation. From the energy service demands, it may be noted that most of the energy saved in the EPO scenario by 2030 and 2050 are coming from the cooking sub-sector in both urban and rural households as a result of gradual shift from inefficient traditional three-stone stove system to efficient LPG stoves. This result further validates the fact that cooking is the most energy intensive activity in the Nigeria household sub-sector and greater efforts towards reducing energy demand should be focussed on the energy intensity of cooking. Table 2 shows the detailed energy demand reduction in the EPO scenario. 


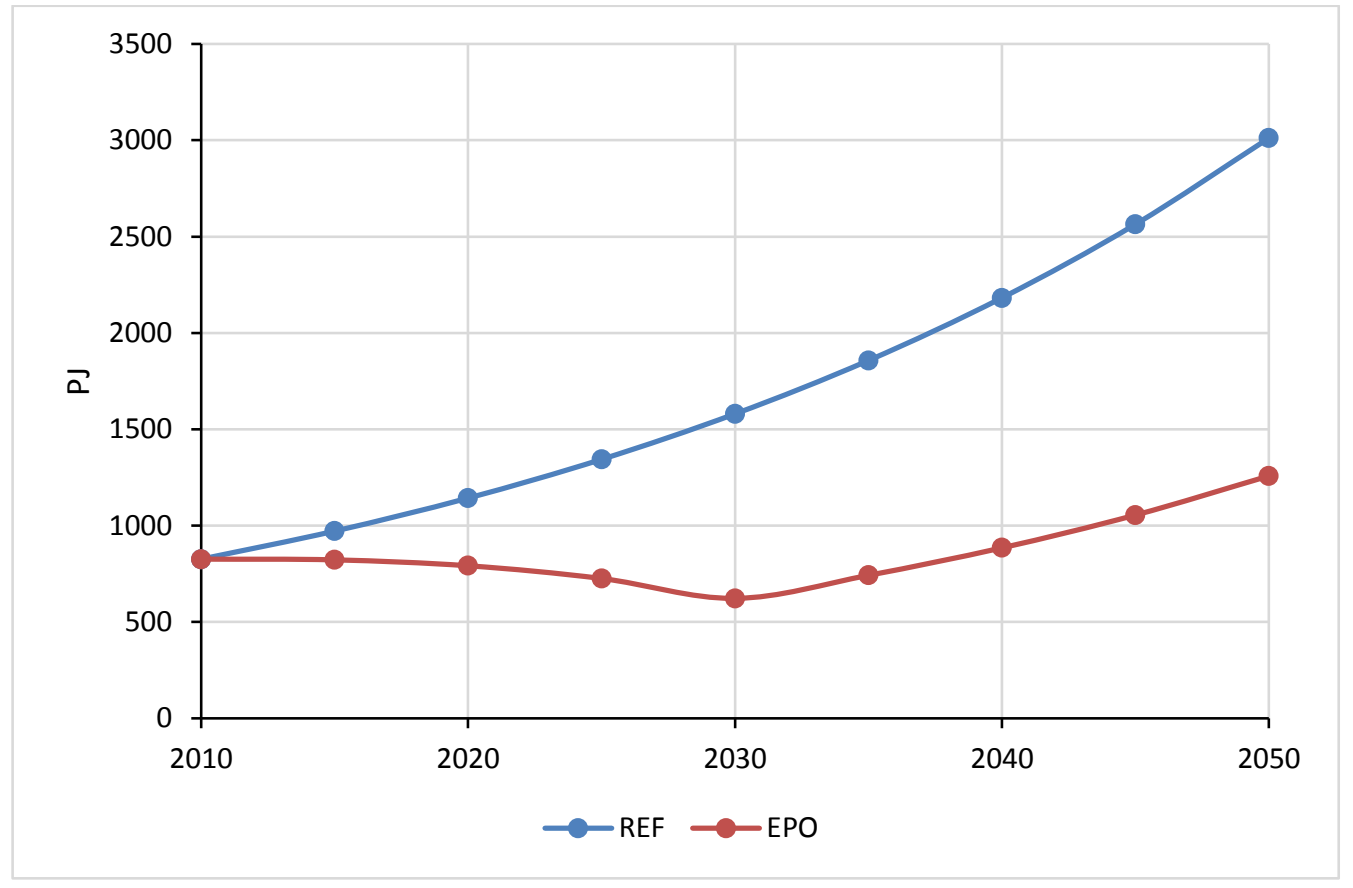

Fig. 5. Comparing total final energy demand reduction.

Table 2. Decomposition of energy demand reduction in EPO scenario compared with the REF scenario (PJ).

\begin{tabular}{lrrrrr}
\hline Branch & $\mathbf{2 0 1 0}$ & $\mathbf{2 0 2 0}$ & $\mathbf{2 0 3 0}$ & $\mathbf{2 0 4 0}$ & $\mathbf{2 0 5 0}$ \\
\hline Urban total & - & -129.8 & -415.5 & -668.4 & $-1,061.2$ \\
Cooking & - & -109.2 & -357.4 & -575.0 & -912.9 \\
lighting & - & -7.9 & -20.5 & -33.0 & -52.4 \\
Refrigeration & - & -0.9 & -2.9 & -4.6 & -7.3 \\
Air conditioning & - & -0.0 & -0.1 & -0.2 & -0.3 \\
Water heating & - & -9.9 & -28.4 & -45.8 & -72.6 \\
Others electric & - & -1.9 & -6.1 & -9.8 & -15.6 \\
Rural total & - & -221.4 & -542.2 & -629.1 & -692.3 \\
Cooking & - & -220.2 & -529.1 & -614.0 & -675.6 \\
lighting & - & 1.9 & -6.2 & -7.2 & -7.9 \\
Refrigeration & - & -0.1 & -0.2 & -0.2 & -0.2 \\
Air conditioning & - & -0.0 & -0.0 & -0.0 & -0.0 \\
Water heating & - & -2.7 & -5.7 & -6.6 & -7.3 \\
Others electric & - & -0.4 & -1.0 & -1.1 & -1.3 \\
Grand total & - & -351.3 & -957.6 & $-1,297.5$ & $-1,753.4$ \\
\hline
\end{tabular}

\subsection{Fuels Consumption}

Ratio of fuels consumption for the two scenarios are shown in Fig. 6. In the REF scenario, biomass energy will continue to dominate the Nigeria household sector with shares of $78.7 \%$ by 2030 and $73.5 \%$ by 2050 . This is followed by kerosene, electricity and LPG with shares of $12.9 \%, 7.9 \%$ and $0.5 \%$ respectively by 2030 . However, by 2050 , the share of kerosene will be $16.4 \%$, electricity $9.4 \%$ and LPG $0.7 \%$. In the EPO scenario, energy efficient appliances are introduced and the consumption of biomass and kerosene which are mainly for cooking will stop by 2030. LPG is seen to be the most consumed fuel by 2030 and 2050 with shares of about $91.7 \%$ and $90.8 \%$ respectively. Talking about reduction in fuel use, electricity consumption will decrease by $58.7 \%$ in 2030 and $59.6 \%$ in 2050 when compared with the REF scenario. The reductions in 
electricity consumption is due to the use of less energy intensive appliances. However, the consumption of LPG will increase by around 73 and 61 times by 2030 and 2050 respectively relative to the REF scenario.

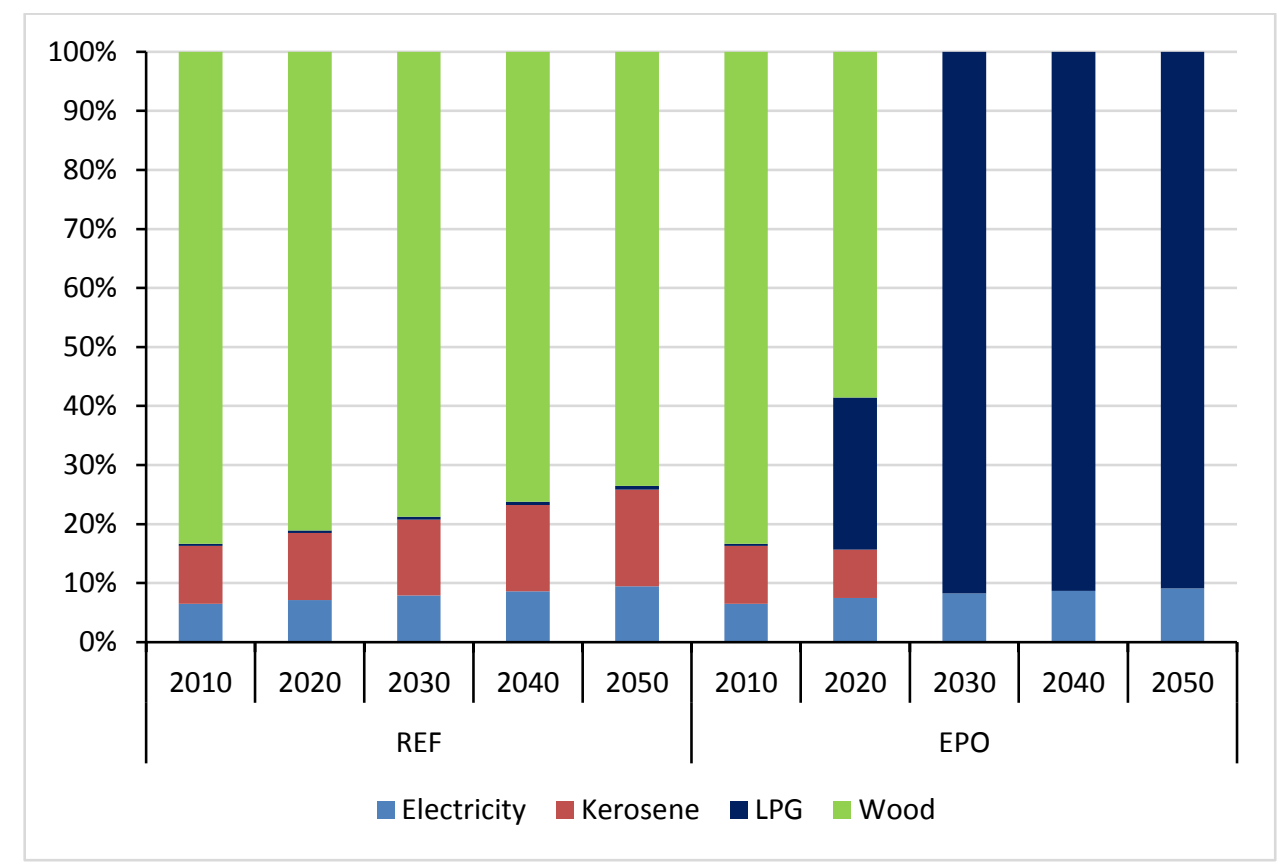

Fig. 6. Fuels demand by ratio under the two scenarios.

\section{3. $\mathrm{CO}_{2}$ Emissions}

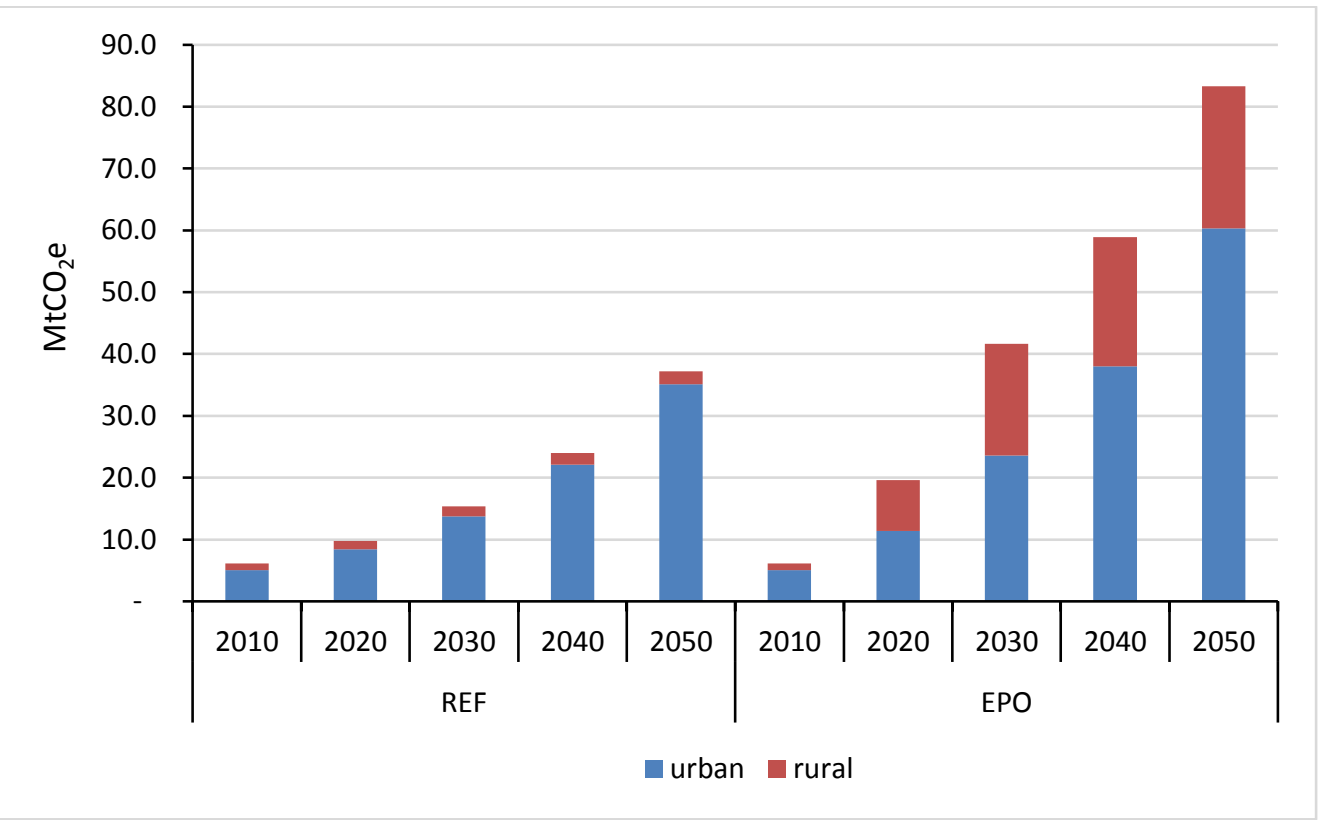

Fig. 7. Total $\mathrm{CO}_{2}$ emissions projection in the two scenarios.

Figure 7 shows the results of the REF scenario and it indicates that $\mathrm{CO}_{2}$ emissions will increase at an annual rate of $4.71 \%$ from $6.1 \mathrm{MtCO}_{2} \mathrm{e}$ (million tonnes of $\mathrm{CO}_{2}$ equivalent) in the base year to $15.4 \mathrm{MtCO}_{2} \mathrm{e}$ by 2030 which represents a $153 \%$ increase. Urban households accounted for a share of $90 \%$ to the final $\mathrm{CO}_{2}$ emissions by 2030 while the rural households account for $10 \%$. By 2050, $\mathrm{CO}_{2}$ emissions is seen to increase by around five times compared to the base year. Since energy consumption in Nigeria is linked to $\mathrm{CO}_{2}$ emissions [47], the high and low increases in $\mathrm{CO}_{2}$ emissions in the urban and rural areas respectively can be attributed to the 
increase in urbanisation and thus the demand for energy services gradually increases in the urban areas and gradually drops in the rural areas. Also, this can be attributed to the fact that LEAP doesn't calculate biogenic $\mathrm{CO}_{2}$ emissions such as emissions from fuelwood in which many Nigerian rural households depend upon for their energy services. LEAP considers biogenic $\mathrm{CO}_{2}$ emitters as net zero emitters. However, there is a caveat here as we are not certain about the sustainability of biomass consumption in Nigeria. Therefore, further study will be required in this context. The detailed $\mathrm{CO}_{2}$ emissions projections for the REF scenario are presented in Table 3. Figure 7 also shows the results of the EPO scenario and it indicates that $\mathrm{CO}_{2}$ emissions will gradually increase at an annual rate of $7.30 \%$, from $6.1 \mathrm{MtCO}_{2} \mathrm{e}$ in the base year to $41.6 \mathrm{MtCO}_{2} \mathrm{e}$ by 2030 which represents about seven times increase with respect to the base year. Urban households accounts for over $50 \%$ of the final $\mathrm{CO}_{2}$ emissions in 2030 and 2050 respectively.

Table 3. Breakdown of $\mathrm{CO}_{2}$ emissions projections in the REF scenario $\left(\mathrm{MtCO}_{2} \mathrm{e}\right)$.

\begin{tabular}{crrrrr}
\hline Branch & $\mathbf{2 0 1 0}$ & $\mathbf{2 0 2 0}$ & $\mathbf{2 0 3 0}$ & $\mathbf{2 0 4 0}$ & $\mathbf{2 0 5 0}$ \\
\hline Urban total & 5.0 & 8.4 & 13.8 & 22.1 & 35.1 \\
Cooking & 5.0 & 8.4 & 13.8 & 22.1 & 35.1 \\
Gas & 0.2 & 0.3 & 0.5 & 0.8 & 1.3 \\
Kerosene & 4.8 & 8.1 & 13.3 & 21.3 & 33.9 \\
Lightinga & 0.0 & 0.0 & 0.0 & 0.0 & 0.0 \\
Kerosene & 0.0 & 0.0 & 0.0 & 0.0 & 0.0 \\
Rural total & 1.1 & 1.3 & 1.6 & 1.9 & 2.1 \\
Cooking & 1.1 & 1.3 & 1.6 & 1.9 & 2.1 \\
Gas & 0.0 & 0.1 & 0.1 & 0.1 & 0.1 \\
Kerosene & 1.0 & 1.3 & 1.5 & 1.8 & 2.0 \\
Lighting & 0.0 & 0.0 & 0.0 & 0.0 & 0.0 \\
Kerosene & 0.0 & 0.0 & 0.0 & 0.0 & 0.0 \\
Grand total & 6.1 & 9.7 & 15.4 & 24.0 & 37.2 \\
\hline
\end{tabular}

${ }^{a} \mathrm{CO}_{2}$ emissions reductions from kerosene lighting couldn't be accommodated in the table because it's so small with respect to the unit $\left(\mathrm{MtCO}_{2} \mathrm{e}\right)$.

It may be noted that $\mathrm{CO}_{2}$ emissions from electricity lighting and electrical appliances were not accounted for in Table 3. This is because, LEAP only calculates emissions from the point/source of production; in this case, the electricity generation plants of Nigeria. Thus, if emissions from source of generation were accounted for in this paper, it is expected that the total $\mathrm{CO}_{2}$ emissions from the household sector will increase significantly above the current values presented in Table 3 owing to the fact that Nigeria electricity supply system is dominated by fossil fuel ( $85 \%$ natural gas) [48].

Figure 8 presents the comparison of the results of the EPO scenario to the REF scenario and it indicates that final $\mathrm{CO}_{2}$ emissions will increase in the EPO scenario by $26.3 \mathrm{MtCO}_{2} \mathrm{e}$ in 2030 which is about $170 \%$ compared to the REF scenario. In the same year, larger percentage (62.4\%) of the increase in $\mathrm{CO}_{2}$ emissions in the EPO scenario is observed to come from the rural households. This is because, by 2030 , over $90 \%$ of the rural households that depend on traditional solid biomass for cooking will now be using LPG and this will, in turn, increase $\mathrm{CO}_{2}$ emissions. The knock-on effect suggests that by 2050 , total $\mathrm{CO}_{2}$ emissions will increase by $46.1 \mathrm{MtCO}_{2} \mathrm{e}$ which represents approximately $124 \%$ increase compared to the REF scenario. This result suggests that the Nigeria energy efficiency policy for the household sector is not effective in terms of $\mathrm{CO}_{2}$ emissions mitigation. Hence, better policies should be developed in order to meet up with the household sector energy demands as well as limit $\mathrm{CO}_{2}$ emissions. Detailed results of the $\mathrm{CO}_{2}$ emissions mitigation are shown in Table 4. 


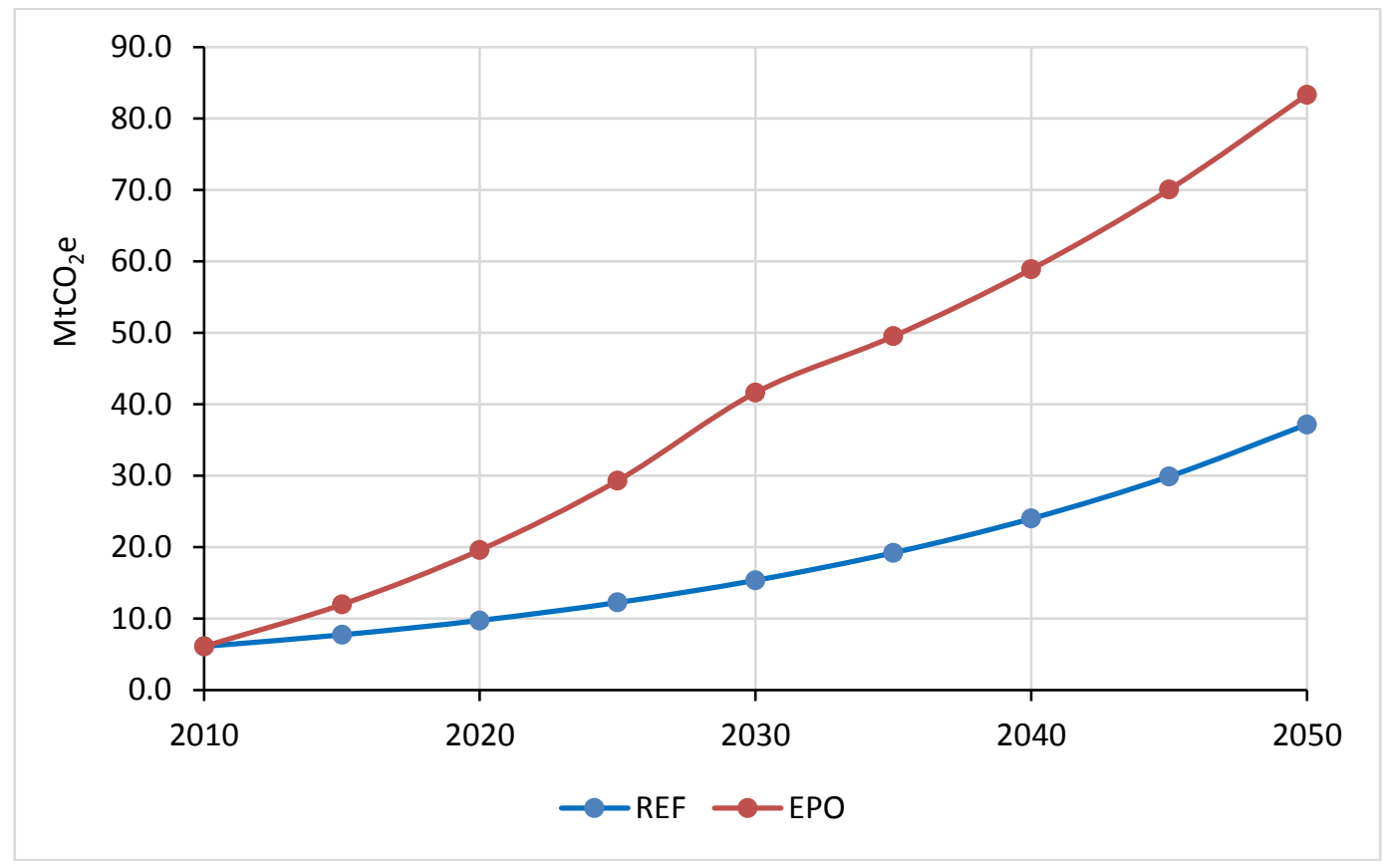

Fig. 8. Comparing total $\mathrm{CO}_{2}$ emissions reduction.

Table 4. Decomposition of $\mathrm{CO}_{2}$ emissions reduction in the EPO scenario compared to the REF scenario $\left(\mathrm{MtCO}_{2} \mathrm{e}\right)$.

\begin{tabular}{lrrrrr}
\hline Branch & $\mathbf{2 0 1 0}$ & $\mathbf{2 0 2 0}$ & $\mathbf{2 0 3 0}$ & $\mathbf{2 0 4 0}$ & $\mathbf{2 0 5 0}$ \\
\hline Urban total & - & 3.0 & 9.9 & 15.9 & 25.2 \\
Cooking & - & 3.0 & 9.9 & 15.9 & 25.2 \\
Gas & - & 7.1 & 23.1 & 37.2 & 59.1 \\
Kerosene & - & -4.1 & -13.3 & -21.3 & -33.9 \\
Lighting & - & -0.0 & -0.0 & -0.0 & -0.0 \\
Kerosene & - & -0.0 & -0.0 & -0.0 & -0.0 \\
Rural total & - & 6.8 & 16.4 & 19.0 & 20.9 \\
Cooking & - & 6.8 & 16.4 & 19.0 & 20.9 \\
Gas & - & 7.5 & 17.9 & 20.8 & 22.9 \\
Kerosene & - & -0.6 & -1.5 & -1.8 & -2.0 \\
Lightingb & - & -0.0 & -0.0 & -0.0 & -0.0 \\
Kerosene & - & -0.0 & -0.0 & -0.0 & -0.0 \\
Grand total & - & 9.8 & 26.3 & 34.9 & 46.1 \\
\hline
\end{tabular}

${ }^{\mathrm{b}} \mathrm{CO}_{2}$ emissions reductions from kerosene lighting couldn't be accommodated in the table because it's so small with respect to the unit $\left(\mathrm{MtCO}_{2} \mathrm{e}\right)$.

A new energy policy (NEPO) scenario is developed in order to understand how changes in policy could impact the total $\mathrm{CO}_{2}$ emissions with respect to the EPO and REF scenarios. We consider the option of changing the cooking equipment of all households in both urban and rural areas by 2030 . We assume that by 2030 and beyond, the share of cooking technologies in the urban households will be as follows: $30 \%$ LPG, $55 \%$ electricity and 15\% improved wood stove while in the rural areas it will be 30\% LPG, $60 \%$ improved wood stove and $10 \%$ electricity. We also assume that the inefficient traditional woodstoves are replaced with the improved woodstoves having efficiencies of $45 \%$ while other variables remain at EPO scenario levels.

The result of the new scenario (Fig. 9) shows that with the introduction of new policies (NEPO scenario), $\mathrm{CO}_{2}$ emissions will fall by $70 \%$ in both 2030 and 2050 which represents 29.1 and $58.3 \mathrm{MtCO}_{2} \mathrm{e}$ reduction with respect to the EPO scenario. Furthermore, when compared with the REF scenario, it was observed that $\mathrm{CO}_{2}$ emissions will fall by $18.8 \%$ (2.9 $\left.\mathrm{MtCO}_{2} \mathrm{e}\right)$ by 2030 and $32.8 \%\left(12.2 \mathrm{MtCO}_{2} \mathrm{e}\right)$ by 2050 . Hence, we may infer that there is the need to incorporate some new policy programs in the NREEEP from the perspective 
of GHG mitigation. Moreover, from energy demand side, our analysis suggests that final energy demand in the NEPO scenario will reduce by around $3.3 \%$ by 2050 relative to the EPO scenario. Thus, creating a better trade-off between final energy consumption and $\mathrm{CO}_{2}$ emissions in the Nigerian household sector. Furthermore, the biomass that will be saved in the NEPO scenario can be used to replace the fossil fuels used in firing boilers in the Nigerian industrial sector which will in turn, further reduce the total $\mathrm{CO}_{2}$ emissions of the country.

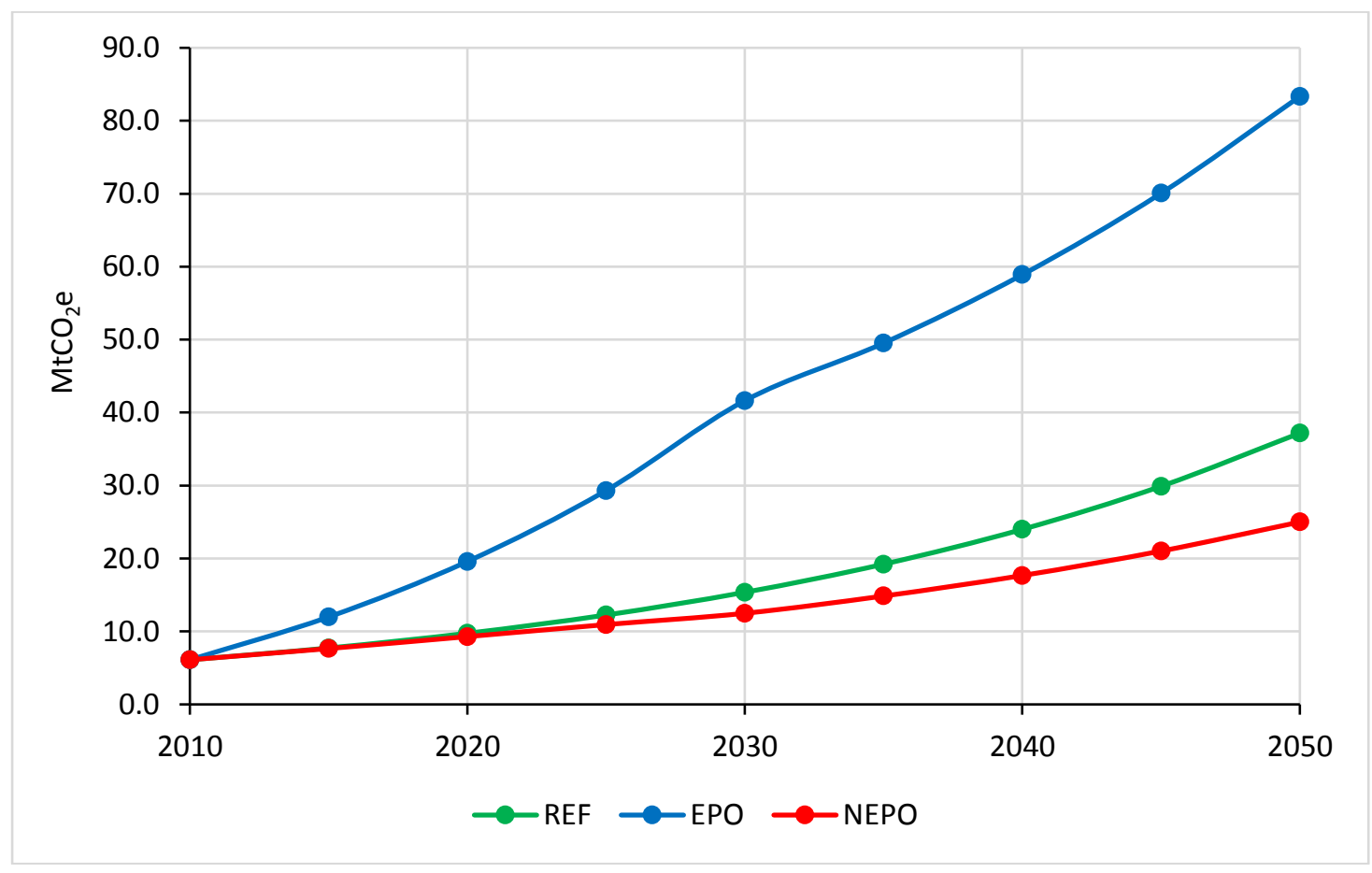

Fig. 9. Impact of new energy policy on $\mathrm{CO}_{2}$ emissions.

\section{Conclusions and Recommendations}

A preliminary attempt has been undertaken in this paper towards analysing the energy demand and $\mathrm{CO}_{2}$ mitigation potentials of the Nigerian household energy policies. We disaggregated the Nigeria household energy service demands into six, which are cooking, lighting, refrigeration, air conditioning, water heating and other electrical appliances for both the urban and rural households. Among all these energy services, cooking continues to remain the most energy intensive activity in the Nigeria residential sector even across the two scenarios. Increase in electrification was also identified to have a similar effect on energy consumption. Our analysis suggests that achieving one goal might impede the realisation of another desirable goal. Nigeria has the potentials of saving huge amount of energy if the conventional pattern of energy usage is changed. However, this will not have a corresponding effect on climate change mitigation most especially in the cooking sub-sector, in the sense that moving away from the use of traditional biomass to LPG for cooking by all households will significantly increase $\mathrm{CO}_{2}$ emissions. Hence, low-carbon cooking alternatives are required.

To keep the journey towards low-carbon development in Nigeria on the right track as related to the household sector, it is recommended that the use of biogas from wastes, liquid biofuels, improved wood stoves, efficient electric stoves and solar cookers for cooking should be integrated into the NREEEP. In addition to these, we also recommend that these policies should be sustained beyond 2030 and further energy savings and $\mathrm{CO}_{2}$ mitigation policies should be introduced as new and environmentally friendly cooking technologies are developed. However, there exist technological, financial, political and institutional challenges with regards to deploying these low-carbon technologies in the Nigeria residential sector. Many households especially those in the rural areas are not aware of these technologies and thus, more effort is needed in organising awareness programs. Research and development should be accelerated in the country to develop efficient, affordable and clean cooking fuels and technologies. Renewable energy technologies like solar 
cooker requires huge initial capital outlay thus, support in the form of financial/fiscal incentives are still required. With respect to political and institutional frameworks, the National Assembly should back the NREEEP with an act of parliament given the numerous potentials it can bring in the context of energy security and low-carbon economy. This action will also provide a road map of low-carbon development for subsequent governments. Furthermore, the executive arm of government should intensify efforts in strengthening the Energy Commission of Nigeria (ECN) and the Federal Ministry of Environment (FMENV) who are in charge of energy and climate policies respectively, in order to carry out their mandates effectively. This is because, only when policies are backed with the appropriate measures of full implementation can the benefits of the policies be seen.

We suggest going further with this study by assessing the economic implication of the NREEEP as well as other co-benefits it can bring such as the reduction of deaths due to indoor air pollutants. Finally, it is worthwhile to state that our analysis has been limited due to non-availability of data which is a major problem in Nigeria. Notwithstanding, we tried as much as possible to rely on the local data available. Data from foreign organisations was used only where we couldn't find local data, and we made some assumptions based on previous experiences and local experts' opinions. While acknowledging these limitations, we believe that our analysis will be useful to Nigeria policy makers. They can use our results as a preliminary evidence to assess the effectiveness of different household energy policies in order to formulate strategies to help achieve international climate agreements, satisfy unmet energy demand as well as have insights for policy decisions beyond 2030.

\section{References}

[1] R. K. Pachauri and L. A. Meyer, "Synthesis Report: Contribution of Working Groups I, II and III to the 5th Assessment Report of the Intergovernmental Panel on Climate Change," Geneva, Switzerland, 2014.

[2] P. Attaviriyanupap, "Status of renewable energy in Europe, U.S., and Japan," Engineering Journal, vol. 14, no. 3, pp. 57-70, Jul. 2010.

[3] D. M. Rahman, N. Bin Sakhawat, R. Amin, F. Ahmed, and F. Ahmed, "A study on renewable energy as a sustainable alternative for ensuring energy security in Bangladesh and related socio-economic aspects," Engineering Journal, vol. 16, no. 2, pp. 47-52, Apr. 2012.

[4] K. Kumar.N, V. Subramaniam, and V. Subramaniam, "Real time clock based energy efficient automatic dual axis solar tracking system," Engineering Journal, vol. 22, no. 1, pp. 15-26, Jan. 2018.

[5] FGN. (2013). Nigeria Post-Disaster Needs Assessment: 2012 Floods [Online]. Available: https://www.gfdrr.org/sites/gfdrr/files/NIGERIA_PDNA_PRINT_05_29_2013_WEB.pdf [Accessed: 19 Apr. 2017]

[6] FGN. (2015). Nigeria Intended Nationally Determined Contribution [Online]. Available: http://www4.unfccc.int/ndcregistry/PublishedDocuments/Nigeria First/Approved Nigeria\%27s INDC_271115.pdf [Accessed: 6 Jun. 2017]

[7] ECN. (2014). National Renewable Energy and Energy Efficiency Policy (NREEEP) [Online]. Available: http://www.energy.gov.ng/index.php?option=com_docman\&task=doc_view\&gid=109\&Itemid=49 [Accessed: 10 Jul. 2017]

[8] P. C. Stern, K. B. Janda, M. A. Brown, L. Steg, E. L. Vine, and L. Lutzenhiser, "Opportunities and insights for reducing fossil fuel consumption by households and organizations," Nat. Energy, vol. 1, no. 16043, 2016.

[9] N. Davis, "Determination of emission factors from back-up generators. Center for environmental research and technology," University of California at Riverside, 2004. Available: http://www.energy.ca.gov/research/notices/2004-10-06_seminar/2004-10-06_DAVIS.PDF [Accessed: 5 Sep. 2017]

[10] A. Q. Jakhrani, A.-K. Othman, A. R. H. Rigit, and S. R. Samo, "Estimation of carbon footprints from diesel generator emissions," in Proc. International Conference on Green and Ubiquitous Technology, 2012, pp. 78-81.

[11] T. A. Boden, G. Marland, and R. J. Andres, "Global, regional, and national fossil-fuel $\mathrm{CO}_{2}$ emissions," Carbon Dioxide Information Analysis Center, Oak Ridge National Laboratory, U.S. Department of Energy, Oak Ridge, Tennessee, U.S.A., 2016. 
[12] P. Forster, V. Ramaswamy, P. Artaxo, T. Berntsen, R. Betts, D.W. Fahey, J. Haywood, J. Lean, D.C. Lowe, G. Myhre, J. Nganga, R. Prinn, G. Raga, M. Schulz, and R. Van Dorland, "Changes in Atmospheric Constituents and in radiative forcing," in Climate 2007: The Physical Science Basis. Contribution of Working Group I to the Fourth Assessment Report of the Intergovernmental Panel on C limate Change. Cambridge, United Kingdom and New York, NY, USA: Cambridge University Press, 2007.

[13] S. Messner, "Journal of evolutionary economics.', J. Evol. Econ., vol. 7, no. 3, pp. 291-313, 1997.

[14] T. Fleiter, E. Worrell, and W. Eichhammer, "Barriers to energy efficiency in industrial bottom-up energy demand models-A review," Renew. Sustain. Energy Rev., vol. 15, no. 6, pp. 3099-3111, 2011.

[15] A. Herbst, F. Toro, F. Reitze, and E. Jochem, "Introduction to energy systems modelling," Swiss J. Econ. Stat., vol. 148, no. 2, p. 112, 2012.

[16] N. Neshat, M. R. Amin-Naseri, and F. Danesh, "Energy models: Methods and characteristics," J. Energy South. Africa, vol. 25, no. 4, pp. 101-111, 2014.

[17] C. Heaps. (2002). Integrated Energy-Environment Modeling and Leap [Online]. Available: http://forums.seib.org/leap/Slides/LEAPSlides.ppt 5. [Accessed: 29 Jan. 2017]

[18] P. S. Bodger and D. G. May, "A system dynamics energy model of New Zealand," Technol. Forecast. Soc. Change, vol. 41, no. 1, pp. 97-106, Feb. 1992.

[19] R. Kannan and N. Strachan, "Modelling the UK residential energy sector under long-term decarbonisation scenarios: Comparison between energy systems and sectoral modelling approaches," Appl. Energy, vol. 86, no. 4, pp. 416-428, 2009.

[20] S. R. Utsav and M. N. Amrit, "Energy consumption and scenario analysis of residential sector using optimization model-A case of Kathmandu Valley," in Proc. IOE Graduate Conference, Institute of Engineering, Kathmandu, Nepal, 2014, vol. 2.

[21] N. A. Ejigu, "Energy modelling in residential houses: A case study of single family houses in Bahir Dar city, Ethiopia," Master of Science Thesis, KTH School of Industrial Engineering and Management, 2016. Available: https://kth.diva-portal.org/smash/get/diva2:900564/FULLTEXT01.pdf [Accessed: 7 May 2017]

[22] F. I. Ibitoye, "The millennium development goals and household energy requirements in Nigeria," Springerplus, vol. 2, no. 1, p. 529, 2013.

[23] I. C. Ezema, A. O. Olotuah, and O. I. Fagbenle, "Evaluation of energy use in public housing in Lagos, Nigeria: Prospects for renewable energy sources," Int. J. Renew. Energy Dev., vol. 5, no. 1, pp. 15-24, 2016.

[24] M. A. Waheed, A. O. Oni, D. A. Fadare, and M. A. Sulaiman, "Assessment of household energy utilization in Ibadan, southwestern Nigeria," J. Energy Eng., vol. 138, no. 4, pp. 179-184, Dec. 2012.

[25] E. K. O. Kadiri and O. A. Alabi, "Household energy consumption pattern in Offa City, Kwara State Nigeria," J. Sci. Res. Reports, vol. 3, no. 11, pp. 1499-1506, 2014.

[26] I. O. Adelekan and A. T. Jerome, "Dynamics of household energy consumption in a traditional African city, Ibadan," Environmentalist, vol. 26, no. 2, pp. 99-110, Jun. 2006.

[27] A. Shittu, A. Idowu, A. Otunaiya, and A. Ismail, "Demad for energy among households in Ijebu division, Ogun State, Nigeria," Agrekon, vol. 43, no. 1, 2004.

[28] Y. Irimiya, I. A. Humphery, and I. I. Aondover, "Assessment of energy use pattern in residential buildings of Kano and Kaduna northern Nigeria," Am. J. Eng. Res., vol. 02, no. 10, pp. 2320-847, 2013.

[29] M. O. Oseni, "Households' access to electricity and energy consumption pattern in Nigeria," Renew. Sustain. Energy Rev., vol. 16, no. 1, pp. 990-995, 2012.

[30] H. Gujba, Y. Mulugetta, and A. Azapagic, "The household cooking sector in Nigeria: Environmental and economic sustainability assessment," Resources, vol. 4, no. 2, pp. 412-433, 2015.

[31] O. Abimbola, A. Amori, O. Omotosho, I. Igbode, D. Omoyeni, and A. Ajayi-Banji, "Investigation of energy use pattern and emission discharge in Nigeria: A case study of south west zone," Int. J. Eng. Technol. Innov., vol. 5, no. 1, pp. 56-65, 2015.

[32] IEA. (2017). Report of Nigeria Balances [Online]. Available: https://www.iea.org/statistics/statisticssearch/report/?country=Nigeria\&product=balances [Accessed: 18 Oct. 2017]

[33] NBS. (2012). LSMS-Integrated Surveys on Agriculture: General Housebold Survey Panel 2010/11 [Online]. Available: http://microdata.worldbank.org/index.php/catalog/1002 [Accessed: 6 Sep. 2017]

[34] WHO. (2007). "Indoor air pollution: National burden of disease estimates [Online]. Available: http://www.who.int/indoorair/publications/indoor_air_national_burden_estimate_revised.pdf [Accessed: 20 Mar. 2017] 
[35] F. I. Ibitoye, "The millennium development goals and household energy requirements in Nigeria," Springerplus, no. 2005, pp. 1-9, 2013.

[36] M. A. Babatunde and M. I. Shuaibu, "The demand for residential electricity in Nigeria: A bound testing approach," in Proceedings of 2nd International Workshop on Empirical Methods in Energy Economics, University of Alberta, Edmonton, AB, Canada, 28-29 Aug. 2009.

[37] ECN, FMENV, UNDP, and GEF. (2013). 'End-use metering campaign for residential houses in Nigeria [Online]. Available: https:/ / www.google.co.uk/url?sa $=\mathrm{t \& rct}=\mathrm{j} \& \mathrm{q}=\& \mathrm{esrc}=\mathrm{s} \&$ source $=$ web\&cd $=3 \& v e d=0$ ahUKEwil9YC 3p5DSAhWsDsAKHWyBBQ4QFggiMAI\&url=http $\% 3 \mathrm{~A} \% 2 \mathrm{~F} \% 2 \mathrm{Fwww}$.ng.undp.org $\% 2 \mathrm{~F}$ content $\% 2$

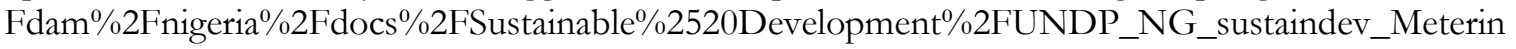
g_Campaign.pdf\%3Fdow [Accessed: 11 Apr. 2017]

[38] Stockhom Environment Institute (SEI). (2005). LEAP: Long-range Energy Alternative Planning System, User Guide for LEAP 2005 [Online]. Available: http://unfccc.int/resource/cd_roms/na1/mitigation/Module_5/Module_5_1/b_tools/LEAP/Manu als/Leap_Use_Guide_English.pdf [Accessed: 17 Nov. 2017]

[39] UN. (2015). World Population Prospects - Population Division - United Nations [Online]. Available: https://esa.un.org/unpd/wpp/ [Accessed: 25 Apr. 2017]

[40] B. O. Achunine, National Trends in Housing-Production Practices in Nigeria. Case Study Prepared for UNCHS, Nairobi. 1993.

[41] NPC. (2017). Censuses [Online]. Available: http://www.population.gov.ng/index.php/ censuses [Accessed: 25 Apr. 2017]

[42] NBS. (2010). Harmonized Nigeria Living Standard Survey 2009/10: Core Welfare Indicator Questinnaire Survey 2009 (Part A) [Online]. Available: http://www.nigerianstat.gov.ng/pdfuploads/HARMONIZED NIGERIA LIVING STANDARD SURVEY 2009 Part A.pdf. [Accessed: 2 May 2017]

[43] C. Robertson, N. Ndebele, and Y. Mhango. (2011). Renaissance Capital: A Survey of the Nigerian Middle Class [Online]. Available: http://www.fastestbillion.com/res/Research/ Survey_Nigerian_middle_class-260911.pdf [Accessed: 3 May 2017]

[44] NPC. (2004). Nigeria Demographic and Health Survey 2003 [Online]. Available: https://www.dhsprogram.com/pubs/pdf/FR148/FR148.pdf [Accessed: 30 Sep. 2017]

[45] ECN. (2015). Nigeria Energy Calculator 2050 (NECAL 2050) Report [Online]. Available: http:/ / www.energy.gov.ng/index.php?option=com_docman\&task=doc_view\&gid=123\&Itemid $=49$ [Accessed: 14 Oct. 2017]

[46] F. Bello. (2014). Consumer Energy Use \& Customer Education in Nigeria [Online]. Available: http://pubs.naruc.org/pub/5375ED8C-2354-D714-510D-1689B421C333 [Accessed: 7 May 2017]

[47] N. V. Emodi and K.-J. Boo, "Decomposition analysis of $\mathrm{CO}_{2}$ emissions from electricity generation in Nigeria," Int. J. Energy Econ. Policy, vol. 5, no. 2, pp. 565-573, 2015.

[48] NPBR. (2015). Nigeria Power Baseline Report [Online]. Available: http://www.nesistats.org/uploads/3/6/3/6/3636925/20150916_nigeria_energy_power_report_final. pdf [Accessed: 12 Oct. 2017] 